\title{
Yoruba Proverbs as Expression of Socio- Cultural Identity in the South-Western, Nigeria
}

\author{
OLANREWAJU, Felicia Titilayo Ph. D \\ Gani Belo Library \\ Federal College of Education, Abeokuta \\ Ogun State \\ Nigeria
}

\begin{abstract}
The paper highlights the use of proverbial expressions as means for expressing some socio-cultural identities among the Yoruba people of south western Nigeria. Within the Yoruba traditions, values, and norms that are verbally expressed through proverbs, there are some inherent cultural traits that are easily identified with by both the speakers and listeners. For effective understanding of these proverbs, a brief historical background of the Yoruba ethnic group is considered. The theoretical framework used is on Diderik Baten's Contextual Theory of Meaning. It holds that the meanings of sentences in terms of actions and observations are seen in relation to the functions performed relating to the background beliefs. The study reveals that proverbs are used directly, indirectly as tools for bringing out inherent traits that run through a particular group of people; the Yoruba are culturally unified with such traits as hard work, tolerance, perseverance, politeness, ethical norms and common sense. It is recommended that its study be given prominence in the curricular of schools and tertiary institutions in Nigeria. Proverbs are strong tools for identity among the peaceful nation.
\end{abstract}

Keywords: Culture, Cultural Identity, Identity, Proverbs, socio-cultural

\section{Introduction}

The Yoruba people lived in the Southwestern part of Nigeria where they are known for their rich, all-encompassing and unblemished cultural heritages. They have several ways of impacting ethical virtues in the younger generations. These virtues become the strong cords by which the young get identified with the older generations of the land. One of such ways is the unique manner with which they dished out proverbs in all their life situations. The Yoruba people are equally popular in their use of proverbs to solve related problems such as hunger, love, hatred, pleasure among other things (Makinde, 2014). This is affirmed by Salawudeen, (2014), that Yoruba proverbs by nature, are multi-faceted and contextual because they offer interpretations to different things at different times. Hence, Yoruba proverbs have been used differently to preserve the indigenous ways of life such as the people's diverse cultures which are embedded in such things as practices, competencies, ideas, values, norms, ethics and the needed etiquettes of the land and the traditional beliefs of the people. All the above socio-cultural variables are the source of ties that bind members of same societies together especially, the people of Yoruba, as they get identified with such practices and influenced by such as well. This point is affirmed in Makinde, (2014) that the culture that we are embedded in inevitably influences our views for the fact we all operate in similar behavioral background and, at linguistic level. Yoruba proverbs are also used as means by which hidden facts and lessons are ditched out to younger generations without raising much dust.

This paper thus highlights on some of the examples of Yoruba proverbs that help the hearers identified with the uncommon qualities that make them different from other tribes and are easily get accustom to their origin, the moment such are said, without mincing words.

\section{Proverbs and the importance among the Yoruba people}

The use of proverbs is not peculiar to one society; in fact, it is a universal phenomenon that aims at solving certain issues that are related to societal problems. But proverbs are deeply rooted in all the fabrics of Yoruba culture to the extent that almost everybody who knows how to speak his/her indigenous language is an inherent speaker of proverbs. Proverbs exist in many forms across cultures and languages and are used to convey messages which help to guide, guard and control the socio-cultural activities of those who understand them.Adegboyega, (2017), opines that among the Yoruba speaking tribes of Nigeria... proverbs are believed to be a 'conversational condiment' used to flavour speech, taking into consideration its cultural and moral relevance.

Rumide, (2013), affirms also that Yoruba people believe strongly, in the tradition of proverbs, hence, they use them in their day-to-day activities.

In fact, it is a common practice among the Yoruba people that for communication to go smoothly, whether serious, like solving issues or casual, proverbs are used as tools to pass ideas and thoughts across to other people. 
More importantly, the elders mostly use proverbs to prove to the younger ones that, it is their exclusive right to use such to drive some serious points home. Hence, as Taylor, (2013) observes, proverbs are the simple truths of life that contain the ethical, moral and sociological values of a society.

$\mathrm{He}$ also claims that aside the aesthetic and figurative value in proverbs, they present a graphic statement that expresses a truth of experience. Based on this observation therefore, it is plausible to opine that the inherent beauty and delight in proverbs contained in their incontestable perception and acceptance. Thus, Akinmade, (2012) surmises that proverbs remain the most powerful and potent vehicle for culture dissemination from one generation to another. In his opinion, it is difficult to find any human situation; agony, sorrow, joy, distress, that a Yoruba proverbial sayings, would not offer solutions to.

\section{Literature Review.}

For a brief review of rich works done on types, functions and characteristics of Yoruba proverbs, many scholars such as: Fabunmi, et al, (2005), Ojo, (2006): Fasiku, (2006); Ajibade, ( 2006); Adeyemi, etal, (2009); Ogunwale, (2012) and others too numerous to mentioned have confirmed the miscellaneous nature of Yoruba proverbs, which are found within the contexts of various disciplines. For instance, Aderinto, 2014), observes that the Yoruba people use proverbs in public gatherings to communicate special messages, with caution to avoid careless, casual, or thoughtless statements whose damage might outlast lifetimes because proverb carries great psychic properties. Arising from the above circumstances, the Yoruba people assigned proverbs to specific situations especially when matters arising become expediently difficult to describe. At any public meeting, especially, where a non indigene of the Yoruba tribe is, a proverb could be used to pass on a cogent, traditionally laden messages, only, to the understanding of the natives present without the knowledge of the nonnatives. The matter for discussion in this paper is relevant to the above notion of proverbs being used as means to express and appreciate one's culture and socio-cultural traits and to remind the hearers of such proverbs that it is essential for them to draw from the preserved fount of their forefathers' cultural reservoirs.

This explains why proverbs work for easy identification of self when the speaker meant it to be used as cultural influence or attachment, reminder, warning or as identity-of belongings, for an erring child who seems to be indifferent to the traditional and moral ethics of his people. For example, when an elder says:

Yor: A kiiwi fun omodekomaah'eyingan an-ganan, o di igbatikobariete fi boo, koju re o to jaa.Eng -A child is not persistently told to desist from opening his lips to avoid protuberant teeth, afterwards, he alone, bears, the accorded smears.

Socio-cultural:implication here is that, from the cradle to maturity, a Yoruba child is tailored and molded to be a kind of perfectionist acceptable to the society. Thus, they believe that,

Yor: Okeereniolojujinjin ti nmekun sun, igigangan ma gun mi loju, okeerela tin yee.

Eng: charity begins at home.

So, Yoruba Proverbs are pointers to ethics and ethical norms in human interactions and are used to appreciate goodly traits and well behaved attitudes while, without, hesitating, frowns at the bad vices amongst the community members. Generally, proverbs according to Adewoye, in Shittu, (2006. P.70), evolved with the growth and development of the society, it reflects diverse aspects of a people's culture, beliefs, traditions, ethics, social and political institutions and others.

\section{Proverbs as means for cultural identity: Towards a definition of culture and identity}

Proverbs are pithy sayings which have independent meanings of their own. Though they are sentences structurally, but are utterances, semantically. They could equally be said to be cultural texts applying some universality of meaning and interpretations that appeal to both individuals and collective consciousness of the users and are therefore signs from other cultures.

For effective discussion of the topic, the other key concepts, cultureand identity need be understood.

Culture- Culture, according to Krefting, (1991), is the norms, values, and behavior patterns that serve as guidelines for people's interactions with others and their environments. Esimaje, Masagbor and Ezirim, (2014), define culture as a range of human activities which are learned, not instinctive and which are transmitted from one generation to another through various learning processes. It is equally perceived as the source of ties emanating from all socially constructed things as practices, competencies, ideas, mores, values, norms, institutions, goals, constitutive rules, of a particular members of the same community. The above imply that the culture that we are embedded in, inevitably, influences our views about life and this in turn determines the types of proverbs to be said at a particular situation.

Since culture has been perceived as shared combination of people's traits, skills and personalities formed within the context of a person's ethnic, racial and educational environments, everyone has a unique personal culture to get attached with. This means that culture is people bound and cannot exist without the society. 
Within the community, there is always a shared understanding that comes from the combination of beliefs, values, attitudes, and behaviors that have provided the foundational base for such a unique heritage that has to be jealously guarded. Hence, the elders, who are the custodians of proverbs in Yoruba society, do not shy away from using proverbs as at when due.

The Yoruba people are culturally conscious of their norms hence, at every gathering and situation, the elderly ones do not hesitate to ditch out norms and ethics that would help imbibe virtues in the younger ones who they believe, are the future leaders of tomorrow, hence this axiom: Yor: Eyinnii di akuko. Eng: Children are leaders of tomorrow.

Most of the proverbs are culturally laden with advice, information, warning and which are easily understood by the hearers even though they are said in a disparaged manner. The cultural lesson is taught in an ironical way so the nonspeakers of the language would be at a loss of understanding the messages contained in the proverbs.Esimaje,Masagbor and Ezirim (2014)confirm the above that the boundaries of one's language are the boundaries of one's world hence, proverbs reflect cultural meanings and reality and are therefore revelatory of the society's culture. Proverbs of a society also reveal the Cultural context, which are, the stable and dynamic norms, values, and behaviors associated with the societal occupational functioning occurs.

\section{Theoretical Background}

Language is one of the main tools through which societal norms, ethics, etiquettes, belief systems and cultural mores are transmitted to younger generations. Every language, has its own culture-laden meanings, which may not be meaningfully decoded into English, This calls for the Yoruba proverbs being translated into English and the reliance on the theories of meanings to get their meanings passed across.

This study considers the contextual theory, an aspect of pragmatics studies (the invisible meaning) which provides frameworks from which meaning can be ascribed and deduced.

Pragmatics is the study of language use which is concerned with the meaning of utterances rather than grammatical sentences or propositions. According to Allott, (2010), Pragmatics focuses on meaning in use: that is, what speakers mean by their utterances, how speakers can mean various things by their utterances, and hearers can grasp what is meant. This means the ability of language users to pair sentences with the context in which they would be appropriate. The above implies that pragmatics is the study of language usage. It describes language from the point of view of the users and how utterances have meanings in situations. Pragmatics studies how language is used in situational contexts that is, how different meanings from the same utterance are used and could be used in different situations.

The contextual theory is therefore a pragmatic theory of meaning which focuses on what the linguistic form is used for, and not what the word actually means. Firth, a proponent of this theory, claims that language was not to be studied as a mental system since it represents a set of events which speakers uttered. Therefore, the most vital fact about language is its social function. Essentially, the theory maintains that a word or sentence will be meaningful only if it is used appropriately in some actual contexts (Ogunsiji,2000). Osisanwo, (2003),surmises that, Pragmatics studies When? Where? and How? a piece of language is being used and which show the situation of context of use with different situations attracting different interpretations or meanings from the same utterance.

From the definitions of various writers above, it could be argued that Pragmatics is the study of how the context and knowledge of the language user impact on the generation of meanings from an utterance.

The theory holds the notion that meanings are multidimensional in nature, there are bound to be different types of meanings. Leech as quoted in (Fasiku,(2006, p.?) identifies seven types of meanings. According to him, meanings are conceptual/denotative, emotional/connotative, collocative, reflective, affective, stylistic and thematic.

All these types of meaning are reflected in Yoruba proverbs and each will be touched briefly

Denotative meaning: is the literal, or plain meaning of a word.

Connotative meaning: is the meaning people associated with words. It is the personal or cultural meaning which is open-ended and depends on "individual experience" or a speaker's meaning (Odebunmi ,2001, p.47).

Collocation (theplacing together of words or phrases), is the meaning of a linguistic form in related to the other forms of words that is expressed in a given context.

Reflected meaning is the sense a word or sentence evokes in a multiple conceptual situation. According to Ogunsiji (2000), reflected meaning arises when oneof the several meanings of a word becomes directly associated with the word to the extent that we tend to forget the other uses of the word.

Affective meaning: arises when language is used to reflect the personal feelings or attitudes of the speaker to the audience. 
Stylistic meaning concerns the social or situational circumstances like geographical location, subject-matter, medium, sex, age.

Thematic meaning: refers to the manner in which messages are organised and ordered for meaningful usage. There are many possible types of meanings which cannot all be explored. However, a proverb may be used to show joy, to pass on ethical norms, to praise, to warn. But in all, the meaning of a proverb depends on when it is used, the ability of the speaker (user), and the cultural and interpretative skills of the listener, the (audience).

However, the ability contained in the context of usage of proverbs is of paramount interest to this study. . It is on this premise that this study examines the expression of socio-cultural identities through some selected Yoruba proverbs. It explains how individual uses proverbs to express what is meant in particular situations, especially when the actual words used appear to mean something different. Yoruba proverbs can appear in different ways and can perform different functions in different contexts. Kirshenblatt-Gimblett (1973) in Fadumiye, (2015)argues, that Proverb's meaning ultimately emerges from a proverb's use in a specific context and that it is not the meaning of the proverb per se that need be our central concern but the meaning of the proverb performances.

According to Fadumiye, (2015), proverbs sum up a situation, pass judgment, recommend a course of action, or serve as a secular past precedents for present action. The choice of words and how it is said, however, will reveal how proverbial sayings are used as silent indicators to showing how younger generations are thought to get identified with the cultures of the land, traditions, values, mores and other socio- cultural traits of the Yoruba people. The cultural lessons are taught in an ironical way so the non-speaker of the language would be at a loss of understanding the message contained in the proverbs.

\section{Proverbs Identified with Diverse forms of Cultural Ethics and Etiquettes in Yoruba Culture}

Yoruba members give an insight to the rich culture and moral values of the Yoruba race. The tone of their proverbs cover the various ways of life of the people in whatever position they find themselves such as:Yor:Itelorun in baba iwa. Eng: Contentment is greater than riches.It is the believe of the Yoruba that a person's peaceful existence and the ability to exhibit perfect life in a stressful situation, shows one's inner mind and reveals one's feelings towards all situations. When it comes to any adverse circumstances of life, Yoruba people remain unruffled. Other similar proverbs identified with such attributes among the Yoruba people are:

\section{Yor: A kiilegbaanile, katunmaawegbaa rode}

Eng: You cannot have Two Thousand at home and begin to find a way of borrowing same amount elsewhere

Proverbs, especially, in Yoruba language enhance the peoples' integrity and equally reveal the extent of their attachment to the cultural ethics of the community. Therefore, members are frequently and always used by eloquent speakers who are known to be vast in the norms, values and etiquettes of the people. Thus, proverbs give a detailed picture of the people as how to behave, what they should do or not at a particular time, their overall beliefs, policy and preoccupations at all time. Some Yoruba proverbs emphasize that human characters cannot be hidden so people are encouraged to be morally behaved as in the following proverbs:

Yor:Eefinniiwa, bi a ba boo mole,yooru jade.

Eng:Behaviour is like a smoke/fume that defies covering up as it ispliable to coming up again.

Yor:Kosi bi ao ti se ifa ti konihuiwaekuro.

Eng: There is no way we can prevent the Ifa oracle from exhibiting similar traits like that of palm kernel.

Yor: Kosi bi ao ti se Ebolo ti koni run igbe

Eng: There is no how anEbolovegetable is prepared that it will not maintain its pungent smell (like feaces).

\section{Cultural Identity:}

The Yoruba people are traditionally inclined with the items as: ekuro, ebolo, ifa, eefin which are culturally identified with and peculiar to Yoruba tribe that hearers easily get acclimatised to as soon as they are mentioned anywhere.

Proverbs can be used to warn listeners to desist from unethical behaviour and to remind them of a point earlier on mentioned or to affirm realistic points raised among the speakers.

Another instance is when a stubborn child keeps behaving somehow that might, at the end, deforms him, the elder may say.

Yor:Akiinikomode ma huehingananganan o di lehinigbatikobaniriete fi boo k' oju re o to jaa.Eng: A child is not warned all the time not to have a protruded teeth, until his lips refused to cover up then he learns to be obedient. (You cannot keep on warning a child who's fond of openinghis mouth of the impending long teeth, until the lips refuse to cover them. 


\section{Or a kiinikomo, maadete, bi o ba ti le da'gbogbe}

Eng: You do not ask a child not to become leprous, if, he, alone can live in the forest).

The above proverbs are warnings and reminders to a child to desist from exhibiting bad traits that mar less he bears the consequences at least for life. This aspect of training and retraining, that is solely peculiar to Yoruba tribe is done ironically, indirectly and softly to impact knowledge, remind, rebuke and dissuade younger ones from behaving unethically in the society.

\section{Proverbs as Essence of Yoruba Tradition and ideologies}

Among the Yoruba society, some proverbs are used as essential tools to pass on some cultural ethos that have become inherently attributed to, and are already identified with the Yoruba, among the larger African societies.

For instance, when a proverb that reflects cultural allusions to rural and farmland living such as in mentioning some farmland implements, animals, communal activities; readers or hearers of such are quickly reminded of their local settings or background and get attached to such. Examples-Aarokiijolasan, omoeniyan lo n danasii Eng:

The hearth does not burn by itself, it is human beings that put fire in it - Though literally, it means that there is no problem without its source as there is no smoke without a gloving light at first instance.

Cultural Identity: But the traditional implements as earthen- ware where local farmers / women prepare food like the modern stove is mentioned to remind the modern people of the local implements used before civilisation. Once this type of proverbs is said, younger ones are made to identify with what their grandparents used for survival before they were born.

Some Yoruba proverbs reflecting customs and beliefs of the Yoruba people, expressing and emphasizing humility, destiny, and hard work as good conduct among the Yoruba are:

\section{Yor:AsọkòboỌmoyemimó, Omoyemi ti rinìhòhòwọọà'}

Eng 'The cloth canno longer cover Omoyemi asOmoyemi has gone to the market nakedly. Yoruba people abhorred a typical act of modern fashions when a lady is involved in going about the streets half naked in the name of societal/ modern fashion. Any attempt to run after covering her with a dress from her shame of nakedness, was too late.

Literal: The hidden secret is already made known, no hide and seek game since the intended matter has gone haywire.

Cultural identity:This shows that the Yoruba, unlike some other tribes in Nigeria, dislike the act of going out nude. The proverb is used by the speaker to let his hearer know that the situation on ground have been marred beyond amendment and solution.

Yor:Orukorere san juwura---Eng: A good name is better than gold

\section{Yor: Ikoko ti yoojegbadun, idi re a gbona}

Eng: The saucepan that will taste of savoury food, will have its bottom glow red with heat. (i.e all in search of distinction with hardships.

\section{Yor: A kiigbinalubosakohuefo, ohun ti eniyanba bin niyooka}

Eng: you cannot sow onions and reap vegetables whatever a man sows, he shall reap.

Cultural identity: TheYoruba believes in perseverance and forthright in whatever they do believing that a man is identified with whatever the skill he chooses to be known with. Hence an efficient, diligent and forthright person would learn to be digenetic in whatever betides along the profession of his choice believing that-

Yor:Igbakii lo bi orere, ojokii to biopaibon-

Eng: Time does not go like a vista and that a day is not as straight as a gun's stem?

Cultural Identity: Once a father or an adult tells an aspiring or suffering younger person with challenges in his choice of work, he quickly summons up courage putting on a die-hard attitude in his choice of profession hoping for the brighter future. The Yoruba people ditch out advices, counseling and admonitions indirectly and persuasively, not with bitterness but surprisingly,to the best understanding of the addressee- a lasting cultural attributes of the morally cultured tribe.

\section{Some Yoruba proverbs as expression of socio- cultural identity:}

\section{Yor-- Bi a kobariadan, aa fi oode se ebo,.,,Ibanujemoniwon fun enitorigaari mu}

Eng- Half a loaf is better than none | Beggers have no choice

Literal- If one does not get an owl for a sacrifice, one surely will go for a parrot, A hungry man is half satisfied, having soaked garri (a local fried powdered cassava flour) as food. 
Cultural identity - Elements such as adan, oode, are local names of birds which are traditionally identified with Yoruba origin and when a younger generation of people hear of such names, they are easily thrilled and get attached with such, feeling good to being part of the Yoruba tribe. And of course, the idea of eating garri, a fried cassava powder which is second to none in Yoruba land as their local custard- nicknamed students' saviour.

Yor:Jaile re ki un ba e koo, idiekankan lo mo.--Eng- Nothing is freely given as advice.

Literal- Remove the roof of your building and all it costs is to get a bundle of spear grass to re-roof it.

Cultural- Identity- The hearers get familiar/ with traditional ways of roofing materials by the Yoruba people in those days instead of modern iron sheets, slates and so in used nowadays.

Yor:- A niki a je ekuruko tan, e tunnigbonowo re sinuawo.--Eng- Bad weeds grow faster.

Literal- Instead of eating a bean cake, as expected and let the plate be wasted, the visitor keeps dragging, refusing to let go of the plates and the remnants.

Cultural- This proverb refers to a type of bean cake-ekuru not the usual name- Akara that is popularly known by all and sundry. So a Yoruba indigene will easily get attracted with this old form of bean cake and it becomes added to his knowledge.

Yor:Enitere, ejilereniagbe fi nkun--Eng: Step by step one goes far/ Little by little, birds build their nests.LiteralCounting one,two drops of water, the gourds fills to the brim.

Cultural:- Traditional counters begins from one, two, and three up till a thousand. Or a filled up gourd/keg of water begins with a little drops. The cultural inclination here is the Yoruba way of counting numbers eni, eeji and the idea of a local gourd as opposed to a plastic keg or water tank used this modern time as storex or to contain water. It is a way of letting the younger ones get to know our system of numbering before civilization of ookan, eeji, etc.

Yor :A kiinaowoasaniileawodi-Eng- You don't rub Peter to pay Paul

Literal- The vultures' money is not spent for the hawk. Thedifferent things from the above help clarified the difference from the two types of birds, which of course, our children could not have discerned.

Cultural: The difference in asaa (the vulture)and awodi (Igunnugun) meanings, which are culturally attached to Yoruba origin are spelt to the hearers through this proverb.

Yor :Bi a bapeeriapaaro, apaaroajako. A o tiikoifanleifa ti se.

Eng: Talk of the devil and he is sure to appear.

Literal: Just at a mention of the Quail, the Quail flew. An ifa oracle has not been fully consulted, it has brought out the result.

Cultural- Quail is a type of bird that is extremely sensitive and active in the bush. A quail would not wait a second at hearing a minutest movement before flying off. Quail is bird that is not known by many people. Equally an ifa oracle or divination is known to be hyper effective in prophetic sayings- The ifa and apaaro are typical attributes of Yoruba people. That the people get identified with geographically.

Yor: Bo petiti ti anda obi, obi a yan

Eng: Good practice makes perfection.

Cultural- Kolanut is identified with Yoruba as a means of future tale-tell stories- The 'nda obi' are identified with the Yoruba traditional means of knowing the future.

Yor:Titarirolaa koi la, bobajinna tan nii di ewa.Eng- There is no rose without a thorn.

Literal- Tribal marks are extremely painful initially, but at the end becomes an established form of beauty.

Cultural: This type of proverb orientates and establishes one of the customs of the Yoruba people- tribal marks with which the Yoruba race is identified wherever they are in the larger societies in Africa.

Yor- Ajipon mii kiiponeeru. Eniyaraniogunngbe.Eng: Early bird catches the worm.

Literal- Any water fetcher early is free of dirty, muddy water.

Cultural- It teaches younger generations the type of water that our fore parents used to fetch- early morning waterthat is crystal clear of muds. It further states what Yoruba people do and how, to get water into their homes.Yor:Wonyin! Ni eebuagba.Eng: Action speaks louder than voice.lLiteral- Smearing remarks suffice an elderly person's insult.

Cultural- This shows a culturally inclined ethics of the Yoruba society that the act of not behaving morally to the elderly ones in the society, has no other meaning but being rude. There are others that are socio-culturally inclined like; warning and advice, settlement of disputes and entertainment. Yor:Eniegun gun lese nii se lakanlaka to alabe lo

Eng:He who is pierced with a thorn must limp off to him who has a knife

When an adult perceives laziness in a young man, he tells him or calls his attention to this by encouraging hard work into him without revealing his notion of calling the man a lazy one but tries to tell him to buck up, without relenting. 


\section{Some of theSocio-Cultural Beliefs peculiar to the Yoruba society:}

The Yoruba people are culturally inclined and believe that whatever one does, be it good or otherwise, that he will reap or take back in the nearest future so one learns that one should do well because: Yor:Agba to bagbinebuika, omo re yoo je e

Eng: The man who puts down the seedling of wickedness, has really planted it on the head of his own child. Okunrin ti ogbinebuikaomo re a je ni be.

Yoruba society relies on proverbs as one of the means to educate the younger ones on their beliefs, philosophy and morality as:Yor:Enisangotoju re wole,konib ${ }^{\text {ee ObaKoso. }}$

Eng: He who witnesses how Sango (god of thunder) enters the ground will never abuse Oba Koso (the king did not hang himself).

Others are:Yor: Igigangangranmágún mi lójú, àtiòkèèrèni a ti í yẹ̀ ẹ̣.

Eng: The only way to avoid a pointed stick from piercing into one's eyes is to walk away from it, at a distance or A stich in time, saves nine. Prevention is better than cure.

Literal meaning: This proverb is used as a warning about an unseen danger accruing fromnegligence, stubbornness or laziness as well as care-free to be cautious

Socio-Cultural: the issue of a long stick being liken to a forlorn, imminentcircumstances, that can ruin one's life should be averted through adequate and prompt planning. Others that are used to identify social attributes are:Yor:Gele o dun bi K"amowe, kamo we ko to ko ye ni.

Eng:The head-tie is not elegant unless it is well tied and even if it is well tied, it is not gracefully shown, unless it suits the wearer.

Socio-cultural:-the need to dress neatly in a pleasing and acceptable manner that portray one of the many corporate ways the Yoruba people would dress and are socially identified in the society.

Yor:Enikankiisupoalaaye. Eng:Nobody marries a woman whose husband is still alive. Socio-Cultural: A socio-cultural etiquette by which the Yoruba are identified. Another man's wife is not bequeath to another man when such a man still lives, all things equal. Others are:

Yor:Gidigidikomee ola, kasise bi eruko da nkan.

Eng: Restless efforts are not criteria for one to be rich, working like a slave does not make one become important.

Yor:Omo to bam'owoo we a baagbajeun.

Eng: A child who knows how to wash his hand will eat with the elders.

For socio-cultural Advice and admonition

Yor:Bi eegun ban le nik'amaar'oju, b'otinreara aye be lo nrearaorun. Eng:If the masquerade chases one, one should not give up because as human beings can get tied, so also the heavenly beings.

Yor: Omi l'odanu, agbekofo.Eng:It is water that spits, the keg has not broken.

Socio- cultural lessons: The above proverbs are given ironically as comfort, admonition, ethical warnings and hope at every point; offered to bereaved parents at the cause of losing their children, to warn a wanton person and so on. This shows the diverse ways through which the Yoruba community get identified with, and pass on their rich culture that binds them together, especially, in times of troubled happenings.Others are:Yor: Agba ti o je ajeiwehinniyooruigbo re d ${ }^{\mathrm{ee}} \mathrm{ele}$.

Eng: An adult who eats all without looking back is doomed to carry home his calabash by himself.

Socio-cultural-An admonition for the elderly ones to always takecognisance of the little ones in need for future advantage.

Yor: Agemo ti bi omo re tan, aimoojo di owoomoalagemo.Eng: A chameleon has given birth to its child, to learn to dance well remains the child's problem.

Socio-Cultural:Parents in the Yoruba setting believe that children should be all ears, sensitive to things that matter, learning to be smart to issues and not to be often reminded of things he had been told as any lawless act of his would be brought to book.There are lots more of these Yoruba proverbs that are given to teach, orientate remind and inform the new generations of the past activities that make their generation different from other tribes in the country, Nigeria.

\section{Summary and conclusion}

From the discussions based on the above selected proverbs, it has been established that the use of Yoruba proverbs to impacting knowledge, especially, ironically among the Youths, makes it expedient for its cultural foresight, survival,self-sensibility and discernment. A Yoruba proverb which says "Bi onígbábá ti șe peigba rẹ, ni amaa ń bá a pe é - whatever name you give to your calabash (good/bad) is what the society will call it.

The elders should not hold their culture loosely for the spirit of modernism which is speedily endangering their cultural values. Perhaps, the older generations should not forget that language is a strong means for the retention of culture, and the two are in inseparable elements among the Yoruba people of southwestern Nigeria. 
The above proverbs provided better understanding of the cultural heritage as a look at the selected proverbs in the paperhave reflected the expression of hopefulness, warning,and provision of cultural and social educational legacy that worth being identified with by the youths. Evidently, this study shows that; proverb is an important tool that has been used to illuminate the society, invigorate the individuals, it has also been used as a binding wire to sustain the norms and cultural values in most indigenous society like the Yoruba before the advent of colonisation and westernisation that affected their initial speedy growth.

One could observe that among the Yoruba people the art of conversation is rated very highly while proverbs are equally taken as the life line of good discussion among the community. This agreed withUsman, Mustafa, and Agu, (2013)'s raised querythat 'what is the matter, fellow, aren't you a Yoruba man?

Must proverbs be explained to you after they are said? From these submissions, it is nakedly believed that Yoruba equally find it desirable and unavoidable to use proverbs effectively in their communication activities. The richness of the proverbial discussions of the elders are superb in the community as powerful ideas, illustrative references, and realistic messages are unraveled through the use of proverbs among the Yoruba society in Nigeria. This paper attempts to affirm that communication matters a lot and that effective communication in Nigeria requires a good mastery of proverbial elements, which bring out real meanings though ironically and sarcastically and impact cultural sensitivity into the hearers than ordinary everyday expressions. The literal, contextual meanings as well as the cultural attributes that identified with Yoruba elements in the selected Yoruba proverbs are underscored.

\section{Recommendations}

Based on the above points, the following recommendations are made:

- Grants should be made available by stakeholders, including cultural experts, governments and language research centres, for the collection and documentation of Nigerian proverbs to boost the indigenous knowledge base of the people.

- The study of proverbs should be given a place in the curriculum of studies for schools and universities in Nigeria. And more importantly, every parent, belonging to this noble race should make it a compulsory affair to train and encourage the children the easiest way of speaking and learning proverbs within and around the home; by speaking such to them at leisure times. Proverbs that unite the country and make the Nigeria calm should be emphasized.

- Much emphasis should be placed on the proverbs that teach tolerance, honesty, hard work and sense of self-worth coupled with sense of acculturation and identity.

\section{References}

Adegboyega, A (2017), "Philosophical Issues in YorubaProverbs" International Journal of African Society, Cultures and TraditionsVol.5(.2) 21-30. European Centre for Research Training and Development (www.eajournals.org). ISSN 2056 - UK 5771(Print), ISSN 2056 - 578X(Online).

Aderinto, S.I. (2014), "The Social Implications of Some Nigerian Yoruba and Ibo Proverbs". European Journal of English Language and Literature Studies, vol.2. (2) 49-55

Adeyemi J. A. and Noah B. (2014). Proverbs and conflict Management in Africa: A study of Selected Yoruba Proverbs and Proverbial Expressions. International Journal of Literature, Language and Linguistics Vol, 1 (1),39- 44 .

Akinmade, C.A (2012) "The Decline of Proverbs As A Creature Of Oral Expression: A Case Study Of Proverb Usage Among The Ondo In The South Western Part Of Nigeria". AfrrevLaligens; An International Journal Of Language, Literature and Gender Studies. Bahir Dar, Ethiopia 1 (2), 127-148.

Akporobaro F.B.O. and Emovon J.A., (1994), Nigerian Proverbs: Meanings and Relevance Today. Lagos: Deparment of Culture, Federal Ministry of Information and Culture, p.1

Allot, N. (2010). Key Terms in Pragmatics. Great Britain: MPG Book Group Limited.

Batens, Diderik, (1975a), Studies in the logic of induction and in the logic of explanation, Brugge, De Tempel. (1975b), Deduction and contextual information, Communication and cognition, 8, pp. 243-'277.

Bello-Olowookere,G. A, (2004) EgberunIjinle owe Yoruba AtiItumo Won Ni Ede Geesi (1000 Yoruba Proverbs and their Translations in English). Lagos; Concept Publications. September. 121p.

Esimaje, Masagbor and Ezirim, (2014), "Proverbs as Iconic and Indexical Markers of Culture: Exploration of the Proverbs Of Four Nigerian Cultures". African Journal of New Writing. (Okike); Ibadan. Number 51, Vol.1.1-17.

Fabunmi, F.A. etal (2005), “Is Yoruba an endangered Language?” Nodic Journal of African

Studiesvol.1(4)

Fasiku, Gbenga (2006), "Yoruba Proverbs, Names and National Consciousness". Journal of Pan African Studies, vol.1, (4).50-63.

OlubunmiA. (2010). “An Ethno-methodology of Selected Yoruba Proverbs". International Journal of Arts and Science. 3(10): 43-231. 
Krefting, L. (1991). The culture concept in the everyday practice of occupational and physical therapy. Physical and Occupational Therapy in Practice, 11, 1-16.

Lawal, R.A. et al. (1997). "A Pragmatic Study of Selected Pairs of Yoruba Proverbs" in Journal of Pragmatics 27 (4) ,635-652.

Lawal, O.A.(2015) "Pragmatic Use of Some Proverbs on Egungun among Yoruba Speakers" IOSR Journal of Humanities And Social Science (IOSR-JHSS) Volume 20, Issue 12, . 2 PP 01-06

Makinde, D.O. (2014) "Modernisation of Creative Culture in modern Nigeria Art". Unpublished Ph.D. Thesis, Department of Fine and Applied Arts, University of Nigeria, Nssuka, Nigeria.

Odebunmi, A. (2001).The English Word and Meaning.Ogbomoso: Critical Sphere. 46-55.

Ogunsiji, A. (2000). "Introductory Semantics" in Babajide, A.O. (Ed.) Studies in English Language. Ibadan: Enicrownfit Publishers..43-59.

Language Attitude and Language Conflict in West Africa. Ibadan: Enicrownfit Publishers. P.30 - 42

Ogunwale, J.A. (2012). A Pragmalinguistic "Study of Yoruba Personal Names". Journal of Literary Onomastics Volume 2, Issue 1, Article 4.

Oladeji, Niyi. 1998. Proverbs as Language Sign-Posts in Yoruba Pragmatic

Ethics. Second Order: An African Journal of Philosophy 1(2): 45.

Osisanwo, W. (2003).An Introduction to Discourse Analysis and Pragmatics. Lagos-Nigeria: Femolus-Fetop Publishers.

Osoba, J. B, (2014), "The Nature, Form and Functions of Yoruba Proverbs: A Socio-Pragmatic Perspective". IOSR Journal of Humanities and Social Science (IOSR-JHSS) Volume 19, Issue 2, Ver. IV (Feb.), PP4456www.iosrjournals.org

Rumide, J.O. (2013), Pragmatic Analysis of Politeness in Yoruba Proverbs. In Issues in Language and Linguistics: Perspectives from Nigeria. Vol 1:137-150.

Shittu, T (2015),'Proverbs as Literary Aesthetics in Ola Rotimi'sOvonramwenNogbaisi and Kurunmi'. Kaduna. Voices; Journal of English Studies. Vol.1 (3). 69-81

Taylor, A, (2003). "The Proverb, Proverbs and their Lessons". In WolfangMeider (ed.) Supplement Series of Proverbium13. Vermont: University ofVermont.

Usman, J, Mustafa, L \&Agu, M, (2013). "Proverb as Determinant of Cultural Identity: The Imperative of the Three Regional Languages in Nigeria. International Journal of Research in Humanities, Arts and Literature (Impact: IJRHAL) Vol. 1, Issue 6, 47-58 